\title{
THE RESEARCH PROGRAM ON THE BEGINNINGS OF THE POLISH STATE BETWEEN POLISH WESTERN THOUGHT AND HISTORICAL MATERIALISM: STRUCTURAL DEVELOPMENTS AND POLITICAL REORIENTATION
}

Focussing on the development of organizational infrastructures, financial constitutions as well as staffing policies of the research program on the beginnings of the Polish state and discussing them in relation to the political framework of post-war Poland, this paper aims to contribute to the understanding of the general preconditions and requirements. Presenting information from archival documents and a close reading of the steps and forms archaeological contributions to the millennial theme have taken, it tries to retrace the development of its thematic and conceptual orientation. This development is presented here as reorientation from a starting point within the realm of the Poznań intellectual centre and thus the Polish Western Thought towards a Warsovian centralization and the implementation of Marxist methodology and, officially at least, Stalinist ideology.

KEY WORDS: research on the beginnings of the Polish state, KBnPPP, post-war Poland, politics of research funding and staffing, Polish Western Thought, Stalinism, Marxist archaeology

A number of attempts has been undertaken so far to describe and evaluate the research program dedicated to the beginnings of Polish statehood within the history of 20th century Polish archaeology. As the majority of those attempts were made from within the discipline itself, they represent mostly general overviews placed within the overall development of Polish archaeology or assessments of the research aims, methodical groundings and interpretation results, discussing them on the basis of published material (e.g. Abramowicz 1991, 146-162; Kobyliński 1996; Lech 1997/98, 65-78; Kurnatowska 1997a; 1997b; Urbańczyk 2000; Moździoch 2008; 2009). Only some of those stud- ies took the political background and its implications into explicit consideration (Urbańczyk 2000; Kobyliński/Rutkowska 2005, 58-63), contributing to a lively discussion about possible political appropriations of the leading research committee, the Kierownictwo Badań nad Poczatkami Państwa Polskiego (KBnPPP) and the archaeological discipline in general in the time of the People's republic and here particularly during Stalinism (especially between Barford 1993; 1995; 1997; 2002; and Lech 1997; 2002; 2007; cf. also Tabaczyński 1995; 2007; 2009; Kobyliński 1991).

Altogether the millennial studies are, with few exceptions, regarded as a stroke of luck for Polish 
archaeology, however for different reasons. Many relate to the generous funding, making it possible to undertake numerous large-scale excavations at historically important sites and in consequence furthering technical and methodical improvement (Kurnatowska 1997a, 152f.; Lech 1997/98, 68; 7678; Urbańczyk 2000, 53). Only few explicitly stress the integration of Marxist theory as an innovative element of the program's research design fuelling the progressive development of Polish medieval archaeology in the second half of the 20th century, which turned it into a sought-after partner for joint international research campaigns (Tabaczyński 2009, 325f.; Barford 1993, 259). And even fewer voiced criticism, especially with regard to many of the excavation results still remaining unprocessed and/or unpublished (Kurnatowska 1997a; Moździoch 1997; 2009; Urbańczyk 2000, 53), but also with reference to the overestimation of the historical meaning applied to the unearthed finds and structures. This overestimation resulted probably from the distinct research focus on strongholds, it nevertheless also conformed to the political expectations (Moździoch 1997; 2009). Further criticism was directed at the disregard of conservational issues while selecting the sites to be investigated and executing the excavations (Wysocki 1997/98, 444 and 446).

Since a complete and detailed history of this program is still unwritten, there seems uncertainty about what actually does count as belonging to the millennial research campaign. Hence, frequently, the work of the KBnPPP 1949-1953, subsequent initiatives on archaeology of early Piast sites within the frame of the Instytut Historii Kultury Materialnej (IHKM) since 1954, and activities connected to the actual celebration of the Millennium itself in 1958/60-1966 are confused and mixed up (e.g. Kobyliński/Rutkowska 2005, 58f. and 70; Urbańczyk 2000, 53). In consequence, not only the political inclinations and anti-clerical tendencies were judged controversially (e.g. Lech 1997/98, 73; Urbańczyk 2000, 53; Noszczak 2002, 63; Kobyliński/Rutkowska 2005, 70-72). This also applies to the question since when and to which extent the millennial program was or had to be grounded on Marxist ideological and theoretical premises and how far previous political motivations and research traditions continued to be in effect, too. Opinions range from attributing the political significance of the millennial program primarily to post-war anti-
German attitudes and the integration of the so-called "regained territories" (Lech 2004, 49) to sensing the whole undertaking as a government driven effort to claim the millennial anniversary as a decidedly secular matter in order to contradict the Church's millennial celebrations of the baptism of Mieszko I (Gąssowski 1998, 38). It has to be remarked, though, that the KBnPPP operation preceded any governmental preparation of the anniversary by years since party organs appointed organizing committees not before 1958 (see below).

With regard to the introduction of communist ideology and Marxist theory some described the KBnPPP unit as an "oasis" of completely independent research during the heyday of Stalinism (Noszczak 2002, 61; Kiersnowski 2000, 66) while others understood this program, explicitly and advantageously so, as "developed within, and enriched by Marxist theory" (Tabaczyński 2009, 325). Often enough it remains unclear to which phase of the archaeological activities dedicated to the origins of Polish statehood between 1948 and 1966 authors refer, and thus the ideological and political references become obscure, too.

A fairly detailed contribution about the millennial archaeological-historical research initiative was offered by the historian Bartłomiej Noszczak (2002, 29-64) as part of a study on the general political framework in approaching the millennium celebrations and the related disputes between government and church. In regard to the research program it is however largely based on interior views presented in contemporary publications and personal statements and thus cannot serve as a critical and contextualizing analysis of the KBnPPP in general. Nevertheless it thoroughly presents the most important primary texts related to this matter. Other historians assessing the situation of the historical sciences in the time of Stalinism refer to the millennial research program only marginally. They tend to assign it a special significance for the Stalinist reorganization of the humanities in the field of archaeology (Hübner 1987, 460-462; Stobiecki 2006, 135f.).

Since the Millennium Project is generally regarded as of crucial importance to post-war Polish archaeology, a detailed and critical history of its proceedings, its ideas and results, but also its societal importance and entanglements with national politics of the 1940s and 1950s seems to be highly desirable and this volume a valuable attempt to prepare the field. 
While concentrating on the development of organizational infrastructures, financial constitutions and staffing policies, and discussing them in relation to the political framework of post-war Poland, this paper aims to contribute to the understanding of the general preconditions and requirements of the KBnPPP's research. Presenting information from archival documents that have been neglected so far and a close reading of the steps and forms archaeologi- cal contributions to the millennial theme have taken, may also help to further retrace the development of its thematic and conceptual orientation. This development of the KBnPPP is presented here as a kind of meaningful shift from a starting point within the realm of the Poznan intellectual centre and thus the Polish Western Thought towards a Warsovian centralization and the implementation of Marxist methodology and, officially at least, Stalinist ideology.

\section{FORMATION OF THE MILLENNIAL RESEARCH INITIATIVE}

The idea of the millennial research seems to have emerged along with the re-establishment of the excavations at Biskupin, Gniezno and Poznań after their interruption by World War II. Especially the latter two had proved as catalysts for archaeological investigations of early Piast places already after their beginnings in the late 1930s. As Polish archaeology beforehand had been mainly concerned with prehistoric periods, research on the Early Middle Ages was now intensified while introducing the question about the beginnings of the Piast rule into archaeology (Żak 1971, 44-46; Brzostowicz 2014; Buko 2014; Wołoszyn in print).

With the foundation of the Institute for the Research on Ancient Slavic Times (Instytut Badań Starożytności Stowiańskich, IBSS) as a branch of the Prehistory Chair at Poznań University in September 1945, a genuine research base had been established in order to resume excavation campaigns foremost in Biskupin, but also in Poznań and Gniezno (Kaczmarek 1996, 241-247).

One year later Witold Hensel published the famous article on the necessity of preparing the upcoming millennial anniversary of the earliest appearance of the first known Piast ruler Mieszko I in written sources (Hensel 1946), which was to be celebrated in the 1960s as Poland's introduction into history. As the excavation results from Gniezno and Poznań had shed light on a whole set of unanswered problems Hensel worked out an extensive outline of research tasks naming several more places for further investigation. With regard to the upcoming millennium he stated, "a period of ca. 20 years divides us from this anniversary, which appears still long, but in reality seems to be too short for undertaking even a portion of those works con- sidered here that have great importance for science and propaganda" (Hensel 1946, 205) ${ }^{1}$.

The realization of the proposed research program in preparation of the millennium Hensel explicitly proposed to be coordinated from Poznań: "At last it is not necessary to argue that the supervision of the organizing and undertaking of this huge scientific venture is to fall to the University of Poznań. After all, in Poznań there are a great many of representatives of different disciplines working on these issues. Moreover Poznań has the historical right to this work. The foundations for the building of our statehood were laid here. And here was most probably its main operational centre, and certainly the seat of the first Polish diocese." (Hensel 1946, $205)^{2}$.

He argued further that the task of the organization and coordination of such an undertaking could be taken upon by the IBSS headed by Józef Kostrzewski due to its capability of working out a clear plan and enabling the provision of corresponding

1 "Okres ca 20 lat, dzielący nas od samego jubileuszu, pozornie jest tylko długi, w rzeczywistości okaże się za krótki dla przeprowadzenia choćby części z pomyślanych tu prac, posiadających wielkie znaczenie naukowe i propagandowe." (Hensel 1946, 205).

2 "Nie potrzebuję wreszcie dowodzić, że kierownictwo w organizowaniu i przeprowadzeniu tego wielkiego przedsięwzięcia naukowego winno przypaść Uniwersytetowi Poznańskiemu. W Poznaniu bowiem nad tymi zagadnieniami pracuje cały szereg przedstawicieli rozmaitych dyscyplin. Poznań też ma historyczne do dzieła tego prawa. Tutaj bowiem kładziono podwaliny pod gmach naszej państwowości. Tu był najprawdopodobniej główny jej ośrodek dyspozycyjny, a na pewno siedziba pierwszego biskupstwa polskiego." (Hensel 1946, 205). 
funds (Hensel 1946, 205). His reference to scholars of different disciplines working on the matter was probably directed at the Western Institute (see below). In essential Hensel's plan aimed for a basically archaeological initiative to be carried out under the aegis of Poznań scholars.

In November 1947 a gathering formally supervised by the General Directorate for Museums and Heritage Conservation (Naczelna Dyrekcja Muzeów i Ochrony Zabytków) was held to discuss the progress and further undertakings of the re-established excavation campaigns in Greater Poland. On this occasion "it was resolved to apply to the Naczelna Dyrekcja for the appointment of a special committee entrusted with the formulation of a research program preparing the Millennium". It was determined that this program should involve "primarily excavation works"3 (Ż[aki?] 1948, 29; Kaczmarek 1996, 169f.).

In consequence the idea of a millennial research project was picked up by the Naczelna Dyrekcja and thus by the Ministry of Arts and Culture superordinate to it - and further developed into a systematic operation. The task of formulating a program for the intended venture was however not assigned to the Poznań archaeological circle as once suggested by Hensel. Instead, Stanisław Lorentz, head of the Naczelna Dyrekcja, asked the young medievalist Aleksander Gieysztor to draft a concrete outline planning the research. To present and discuss Gieysztor's draft a conference with all major Polish archaeologists, historians, art historians and representatives of the Naczelna Dyrekcja was summoned in March 1948 in Warsaw (Gieysztor 1948; Kaczmarek 1996, 170). The letter of invitation to this conference issued in February 1948 reads: „Picking up an initiative of the resolution passed by the commission convened in Gniezno, November 14th last year [...], the General Directorate for Museums and Heritage Conservation summons an interdisciplinary conference of prehistorians, historians and art historians, dedicated to discuss the organization of research on the early history of Poland [...]. The General Directorate for Museums and

3 "W toku obrad [...] postanowiono zwrócić się do Naczelnej Dyrekcji Muzeów o powołanie specjalnej komisji, która opracowałaby program prac przygotowawczych 1000-letniej rocznicy ukazania się Polski na arenie dziejowej. Uchwalono też, że program ten obejmie przede wszystkim prace wykopaliskowe [...]" (Ż[aki?] 1948, 29).
Heritage Conservation at the present time has at its disposal financial and organizational means within its budget, which it intends to utilize in part for the realization of this research" (Archiwum PAN zesp. Manteuffel, T. Sygn. III-192, jedn. 60, 221 $)^{4}$.

The research program Gieysztor presented at this conference naturally took up a much stronger historical focus in comparison to Hensel's article in 1946. And from today's perspective it appears he subordinated archaeology to a certain extent to medievalist demands. While granting both disciplines their respective raison d'être and necessity for the investigation and reconstruction of the (medieval) past, he acknowledged that the historical side should lead the way in formulating an outline of the research problems (Gieysztor 1948, 394), although Hensel's publication had already provided detailed ideas from an archaeologist's perspective. He reasoned that, as the prehistorians' recent interest in early history had been brought about due to the historical science's entreaty, the latter one should remain the one to determine the research steps in that field. Arguing further that early medieval strongholds had been mainly investigated extrinsically only, by means of field surveys, while thorough excavations of sites in question were yet to be undertaken, Gieysztor stated that archaeological research solely on the basis of morphological and topographic criteria was at the time being unable to discern a historically significant hierarchy leading to the most important places of early Piast rule. In contrast to this, information from medieval records would not only provide a chronological frame but could also help identify the (assumed) main places of the early Piast time (Gieysztor 1948, 393f.). Therefore, though explicitly stressing that it should be a cooperation on equal terms, he suggested that the selection of sites to be excavated was to be based upon information gained from written sources.

4 “Naczelna Dyrekcja Muzeów i Ochrony Zabytków podejmując inicjatywę wyrażoną w uchwale komisji zwołanej dnia 14 listopada ub. r. do Gniezna w sprawie prowadzonych tam prac wykopaliskowych, zwołuje konferencję międzyśrodowiskową prehistoryków, historyków i historyków sztuki, poświęconą dyskusji nad organizacją badań wczesnodziejowych w Polsce. [...] Naczelna Dyrekcja Muzeów i Ochrony Zabytków rozporządza w chwili obecnej możliwościami finansowymi i organizacyjnymi, określonymi przez swój budżet, które zamierza w części zużyć na realizację tych badań." (Archiwum PAN zesp. Manteuffel, T. Sygn. III-192/60, 2). 
The excavations were expected to gain "sufficient classification criteria, helping us to approach the problems that are most important for the historian, such as chronology and function of the pre-Polish forts"5 (Gieysztor 1948, 394; cf. Lorentz 1956, 94f.; Noszczak 2002, 32f.). He also claimed the selected places to be dug up entirely and completely, fortification, outer bailey, surrounding settlement and cemetery included (Gieysztor 1948, 395). With all due respect, Gieysztor apparently lacked knowledge about the technical demands of stronghold excavation, which makes it barely possible to excavate one site in total, let alone several ones; nor did he consider any conservational matters.

However, his programmatic suggestions were approved by nearly all scholars present and in nearly all their points, as the discussion minutes show (Gieysztor 1948, 406-412). Only Roman Jakimowicz objected that "the selection of sites should fall to the prehistorians, and not the historians, who may only interpret the achievements of prehistory.
The synthesis will fall to both disciplines individually. The help of the historians in the actual investigations of strongholds seems rather unfeasible" (Gieysztor 1948, 408) . $^{6}$

Obviously the novelty of planning a research enterprise explicitly as a cooperation of archaeologists and historians went along with uncertainties and inconsistencies of the methodical approach, the division of work and its procedural steps. Nevertheless, in consequence of the Warsaw conference, the Naczelna Dyrekcja funded excavation campaigns under the title of a provisional Committee of Research on Early History (Komitet Badań Wczesnodziejowych) already in the current year 1948 at the sites of Gniezno, Poznań, Gdańsk, Szczeczin, Opole, Łęczyca, Kruszwica, Kraków-Wawel, Lednica, Biskupin, Sobótka (Gieysztor 1953, 10; Noszczak 2002, 257 Aneks; AAN MKiSz Dyr. Muz. 3/15; AAN MKiSz Dyr. Muz. 3/25; AAN MKiSz Dyr. Muz. 3/23, 145).

\section{THE APPOINTMENT OF THE KIEROWNICTWO BADAŃ NAD POCZAॄTKAMI PAŃSTWA POLSKIEGO}

It took however until April 1949 until the KBnPPP was officially installed within the Naczelna Dyrekcja, to whom it was directly responsible, appointing Gieysztor as its head (Gieysztor 1948, 412; Noszczak 2002, 36; AAN MKiSz 3/17; 3/141, 1f.).

In a letter to Tadeusz Manteuffel, head of the History Department at the University of Warsaw and in many ways his mentor, in spring 1948 Gieysztor mentioned with reference to the planned research on early history that "at the top, central offices do not move satisfyingly" and thus caused the whole initiative to be stuck (Węcowski 2016, 511) ${ }^{7}$, which seems to be directed either at the general appointment of the KBnPPP and/or the decision on Gieysztor becoming its head. Without relating any further details it seems as if the definitive establishment of the KBnPPP did not occur without problems, it may have been even accompanied by disagreement, as Gieysztor acknowledged in yet anoth-

"[...] po metodycznym zbadaniu grodzisk zdobędziemy wystarczające kryteria klasyfikacyjne, które nam pomogą dotrzeć do najistotniejszych dla historyka kwestii jak chronologia i funkcja grodów prapolskich." (Gieysztor 1948, 394). er letter increasing "irritation at the prehistorians' incompetence" (Węcowski 2016, 510).

According to Gieysztor, being approached by Stanisław Lorentz to take up the lead in the research program came somehow as a surprise to himself. In an interview by Robert Jarocki he remarked that Hensel's publication was only the starting signal, with a meeting for programmatic planning following a few months later under the auspices of Lorentz, who asked Gieysztor in 1948 to undertake the task of preparing this research program (Jarocki 2001, 205). A year after the Warsaw conference, i.e. in February 1949, Gieysztor was informed by Lorentz that he would preside over the newly ap-

6 "Wybór punktów powinien należeć do prehistoryków, a nie historyków, którzy mogą tylko interpretować zdobycze prehistorii. Synteza należeć będzie do obu nauk z osobna. Pomoc historyków w samych badaniach grodzisk wydaje się raczej nierealna." (Gieysztor 1948, 408).

7 "Istotnie inicjatywa utyka już u góry, gdzie ośrodki [nie] ruszają się zadowalająco." (Węcowski 2016, 511).

8 "co do Komitetu, pisałem już o mojej taktyce. Muszę jednak stwierdzić, że są rzeczy nęcące także naukowe, a irytacja wzbiera na nieporadność prehistoryków" (Gieysztor to Manteuffel 06.04.1948, Węcowski 2016, 510). 
pointed Kierownictwo Badań since "the leader should be a medievalist" (Jarocki 2001, 205; also Noszczak 2002, 32). Although Jarocki explicitly asked why Gieysztor himself was chosen, he did not give a specific reason but rather referred to the integrating function the millennium program was to have for both the archaeological and historic disciplines.

Why Lorentz would have wished to engage Gieysztor is understandable since they shared a long acquaintance. Gieysztor was educated at the private gymnasium run by Lorentz' father, and Lorentz himself even was Gieysztor's history teacher there (Kozłowska 2016, 74f.). Further, both, Gieysztor and Lorentz, worked in significant positions in the Underground during the German occupation. After the war Lorentz as director-general of the Naczelna Dyrekcja supervised the monument inventory works, where he employed Gieysztor for a short time. Apparently, apart from Manteuffel, Lorentz exerted considerable influence also on Gieysztor's career in the early post-war years (Jarocki 1996; Anonymous 1974; Kozłowska 2016, 76). Together with his position at the chair of History at the University of Warsaw and several other functions, being made head of the KBnPPP contributed to Gieysztor's smooth raise within the developing new intellectual centre of Warsaw, which in the end also seems to have prevented him from being imprisoned or blackmailed by the Security Service for his former underground activities (Jarocki 1996; Rutkowski 2013, 139-144).

Apart from Aleksander Gieysztor chairing the KBnPPP, Kazimierz Majewski and Zdzisław Rajewski were appointed as vice-chairmen. It is inter- esting to note that both took up important positions almost at the same time they were appointed to it. Majewski was made head of the Museum Department within the Naczelna Dyrekcja for a short time in 1949/50 and even temporarily assigned with the duties of the vice director of this authority (Archiwum PAN zesp. Majewski, K. Sygn. III-275, 92; Anonymous 1970). Rajewski became director of the State Archaeological Museum (Państwowe Muzeum Archeologiczne, PMA) (Noszczak 2002, $37)$. It could be and has been argued that their political orientation did recommend them to hold these offices and their positions in the KBnPPP (Kiersnowski 2000, 65).

It seems however striking why, if not Józef Kostrzewski due to his open rejection of communism and probably being not too keen a supporter of the millennial idea (Urbańczyk 2008, 154), Witold Hensel as the initiator of the whole endeavour was not included in the leading board. It is believed he was disappointed or even frustrated by it (Noszczak 2002, 63), which suggests that this staffing policy was not entirely expected. What is more, Lorentz seems to have been ill-disposed against Hensel, who later recalled being attacked by him on a KBnPPP conference (Urbańczyk 2008, 155). As the planned research program centred on archaeological excavations of early medieval sites, Hensel's experience gained from supervising excavation works at Gniezno, Kłecko and Poznań in the 1930s and 1940s would have been valuable (Urbańczyk 2008, 149-151). But only Rajewski represented the Poznan centre and the disciplinary branch of Preand Protohistoric Archaeology within the KBnPPP group of three, alongside a historian and a classical archaeologist.

\section{STAFFING AND FUNDING}

As the following figures show, a number of field and central branches were established and later on completed by a coordinating Office for the Research on the Beginnings of the Polish State (Biuro Badań nad Poczatkami Państwa Polskiego), managed by the historian Ryszard Kiersnowski (Gieysztor 1948, 12; Noszczak 2002, 49-51).

According to different sources relying on different accounts, the following sites were connected to the KBnPPP program at a certain stage, though it is undetermined if they all were financed out of its budget: Biskupin, Bródno Stare, Cieszyn, Gdańsk, Giecz, Gniezno, the Cherven' towns (grody Czerwieńskie): Czermno, Gródek, Sąsiadka and Lipsko-Polesie, Igołomia, Inowłódz, Kalisz, Kruszwica, Lachmirowice, Ostrów Lednicki, Lutomiersk, Łęczyca, Niemcza, Opole, Poznań (Ostrów Tumski, Katedra, Góra Przemysława), BłonieRokitno, Ślęża, Sobótka, Strzelno, Szczecin, Trzemeszno, Tyniec, the Silesian Walls (Wały Śląskie), Warszawa-Zamek, Kraków-Wawel, Wietrzno-Bóbrka/Krosno (?), Wiślica and Wrocław (AAN MKiSz 
THE RESEARCH PROGRAM ON THE BEGINNINGS OF THE POLISH STATE

Tab. 1. Number of KBnPPP branches 1948-1953 (cf. Noszczak 2002, 38).

\begin{tabular}{|l|l|l|l|}
\hline & Field branches & Central branches & in total \\
\hline$[1948$ & 11 & - & $11]$ \\
\hline 1949 & 25 & - & 25 \\
\hline 1950 & 25 & 4 & 29 \\
\hline 1951 & 24 & 2 & 26 \\
\hline 1952 & 24 & 2 & 26 \\
\hline 1953 & $?$ & $?$ & $?$ \\
\hline
\end{tabular}

Tab. 2. Budget of the KBnPPP.

\begin{tabular}{|l|c|c|}
\hline & preliminary budget in $\mathrm{zl}^{*}$ & $\begin{array}{c}\text { percentage increase according to } \\
\text { Gieysztor** }\end{array}$ \\
\hline 1948 & $9.800 .000 \mathrm{zl}$ & - \\
\hline 1949 & $24.488 .000 \mathrm{zł}^{\mathrm{a}}$ & $100 \%$ \\
\hline 1950 & $75.000 .000 \mathrm{zł}$ & $172 \%+77 \%=249 \%^{\mathrm{b}}$ \\
\hline 1951 & $117.797 .000 \mathrm{zł}$ & $187 \%$ \\
\hline 1952 & - & - \\
\hline 1953 & - & \\
\hline
\end{tabular}

* figures extracted from the preliminary budget of the Naczelna Dyrekcja Muzeów i Ochrony Zabytków (AAN MKiSz Dyr. Muz. 3/16, 63 and 73-75; AAN MKiSz Dyr. Muz.3/17, 59, 68 and 97; AAN MKiSz Dyr. Muz. 3/18, 74; AAN MKiSz Dyr. Muz. 3/23, 140-145).

** figures from Gieysztor (1953, 6), indicating the development of percentage increase of the KBnPPP's budget.

a actual budget in 1949 stated within the preliminary budget for 1950 (AAN MKiSz Dyr. Muz. 3/17, 68).

${ }^{b} 172 \%$ from the KBnPPP's own budget plus $77 \%$ derived from the Ministry of Labour.

Akta tajne Paczka 1, t. 3., cz. II, poz. 14; AAN MKiSz. Dyr. Muz. 3/141; Gieysztor 1953, 10f.; 1955; Noszczak 2002, 257 Aneks).

To realize all those excavation campaigns and accompanying medievalist-editorial, cartographic and natural scientific works, up to 240 academic personnel were employed, and during field season this number increased significantly due to the hiring of numerous field workers (AAN MKiSz Dep. Ochr. i Kons. Zab. 4/2, 31; AAN MKiSz Dyr. Muz. $3 / 18,74)$. Though numbers differ for the particular years, one can assume about 120 to 130 permanent employees, even more non-permanent academic staff and field workers adding up to about 450 persons during field season (Gieysztor 1953, 6).

In regard to the amount of the financial funding of this undertaking, it was repeatedly postulated that it must have been enormous, to an extent that it seemed "unlimited" to contemporaries (Urbańczyk 2000, 55 fn. 2; Lech 1997/98, 66; Noszczak 2002,
55, cf. also Reichenbach 2016). Lorentz stated already at the Warsaw conference back in 1948 that the task of the millennium research was so important that it had to be carried out regardless of the necessary financial and technical demands (Gieysztor 1948,407$)^{9}$.

And indeed, the particular figures taken from the budget of the Naczelna Dyrekcja speak for themselves (see Table 2).

With the increase from the amount of 25 million złoty in 1949 to about 118 million złoty in 1951 the KBnPPP swallowed 3-5\% of the whole budget of the Naczelna Dyrekcja (Noszczak 2002, 39; AAN MKiSz Dyr. Muz. 3/18), which is comparable to the total budget given to the department of museum ex-

9 "Nie uważamy, żeby przy postawieniu tak zasadniczego zagadnienia można było przymierzać zamiary do środków finansowych czy technicznych." (Gieysztor 1948, 407). 
hibitions (AAN MkiSz Dyr. Muz. 3/18, 74). In his final report Gieysztor indicates an increase of the KBnPPP's budget of 87\% from 1949 to 1951, and a reduction in the following year (Gieysztor 1953, 6 ), which does not correspond with the figures given above, but at least shows the raise of the funding, too. With regard to the enormous tasks of monument preservation, reconstruction, inventories and revindication works faced by the Naczelna Dyrekcja in the post-war years, it is astonishing that it was possible to install such a largely funded research project (Lorentz 1956, 57).

A comparison with the excavation budget of the PMA may further illustrate which potential for archaeological investigations the huge funding offered since nearly $82 \%$ of the KBnPPP's budget was swallowed by archaeological works (Gieysztor 1953, 6). Before the millennium program started, the PMA was the major, if not exclusive authority for excavating greater archaeological sites. Likewise funded by the Naczelna Dyrekcja, it received an amount of 3.900 .000 złoty in monthly rates of $325.000 \mathrm{zl}$ in 1948, whereas the first millennial themed research at the mentioned 11 sites in the same year were subsidized with $9.800 .000 \mathrm{zl}$, even before the official authorization of the Kierownictwo Badań had taken place (AAN MkiSz Dyr. Muz. 3/15, 2; AAN MkiSz Dyr. Muz. 3/22, 212-215). In other words, the excavation activities in Poland were more than doubled in 1948 alone, receiving more than two and a half times the amount of funding received by the PMA.

Trying to place the amount of financial support of the KBnPPP within the context of post-war Polish society and politics of science by contrasting it with other scientific or societal endeavours proved difficult. Precise sums of other projects' funding are scarcely published while the changing economic and living conditions as well as numerous monetary reforms of that time complicate reasonable comparisons.

To present at least one example, the Western Institute in Poznań received a one-off payment of $50.000 \mathrm{zl}$ by the government in 1945, estimated by Robert Brier "as a notably high sum for the situation in spring $1945^{\prime \prime 10}$ (Brier 2003, 25). The amount of employed personnel at this institution rose from 46 at the end of 1946 to 60 staff members in spring 1948 (Brier 2003, 40). Only a few years later the KBnPPP disposed, as shown above, of at least twice as much permanent employees and the ministry funding reached eight- to nine-digit annual sums. Even though the millennial research did not take place in the time directly after the war, the political and economic reconstruction of the country was far from being completed in the years 1949-53 (Borodziej 2010, 277f.; 281f.), and it may astound that so much money was spent on an archaeological-historical research project.

\section{TRANSFER INTO IHKM AND THE MILLENNIAL CELEBRATIONS}

Already in 1951 , in the course of the reorganization of the Ministry of Arts and Culture and the foundation of the Polish Academy of Science (Polska Akademia Nauk, PAN), preparations for a transference of the Kierownictwo Badań into the newly founded academy were started. This process took until the end of 1953 and the former millennium research program evidently formed the basis for the IHKM, the new PAN Institute for the History of Material Culture (Dembińska 1965, 209; Abramowicz 1991, 158; Lech 1997/98, 79). Consequently, research explicitly and officially labelled as "Research on the Beginnings of the Polish State" was undertaken only until the end of 1953, and thus until the end of the Kierownictwo Badań, even though a lot of its projects continued and some of the scientific output appeared only many years later in publications and editions.

Kazimierz Majewski in particular had agitated for the establishment of an academy of science and an institute for the history of material culture following the Soviet model in the preceding years, e.g. already in November 1948 on a congregation of the historical-philosophical section of the Wrocław Scientific Society and later at conferences of the KBnPPP (Archiwum PAN zesp. Majewski, K. Sygn. III-275, jedn. 30). After the foundation of the PAN, a planning, later organizing committee, which was chaired by Majewski and included the archaeolo-

10 "für die Verhältnisse des Frühjahrs 1945 ausgesprochen hohe Summe" (Brier 2003, 25). 
gists Witold Hensel, Włodzimierz Hołubowicz, Zofia Podkowińska, Zdzisław Rajewski and Ludwik Sawicki, as well as historian Aleksander Gieysztor, ethnographer Witold Dynowski and Zdzisław Kępiński representing the Naczelna Dyrekcja (Archiwum PAN zesp. Majewski, K. Sygn. III-275 jedn. 30; [Majewski] 1953, 284f.). The offical establishment of the IHKM was eventually authorized on November 19th in 1953 ([Majewski] 1953, 290f.). Majewski was consequentially appointed as its director, but due to illness replaced only about a year later by Hensel, who held this office until 1989. The institute was now responsible for the planning, coordination and realization of research on material culture. Its main focus was directed on the pre- and protohistory of Poland, and in this respect it continued the studies on the beginnings of Polish statehood on a broader scale. In addition to the archaeology of Poland and the Slavic lands, it supervised the archaeology of the Mediterranean area and material culture studies in an ethnographic sense (Hołubowicz 1954; Schild 2013, 20). The range of studies was represented by the four departments of Archaeology of Poland, General Archaeology, History of Material Culture and Ethnography (Zeydler-Zborowski 1954, 93f.).

Taking over the KBnPPP's legacy, the new institute's efforts initially centred on early medieval archaeological sites, however increasingly intensifying research on prehistory. While several of the former KBnPPP field branches were closed, those in Kraków, Poznań, Wrocław, Łódź and Igołomia were continued by the IHKM (Abramowicz 1991, 163; Lech 1997/98, 82f.). The new institute's budget allowed the appointment of 170 academic employees and 23 administrative staff members, striving to retain most of the former KBnPPP staff (Archiwum PAN zesp. Majewski, K. Sygn. III-275, jedn. 30, 12).

Although often confused with the works of the Kierownictwo Badan, archaeologically themed preparation works for the actual millennial celebrations in the 1960 s were a related but essentially different matter. The church had decided in 1956 to start with a celebrational novena already in the following year, anticipating the millennial anniversary of Mieszko I's baptism in 966 year by year with festive services and pilgrimages. As those campaigns received huge public attention the government felt challenged to react with a secular, state-controlled millennial program (Breyer 1968, 88f.; Noszczak
2002, 115). Thus, a resolution issued by the Sejm on February 25th 1958 pronounced the years 19601966 as official period of the millennial celebrations, and a Preparing Committee for the Celebrations of the Millennium of the Polish State (Komitet Przygotowawczy Obchodów Tysiaclecia Państwa Polskiego, KPOTPP) presided by the PAN president was appointed in order to plan the festivities and associated activities (Breyer 1968, 89; Noszczak 2002, 115; Kobyliński/Rutkowska 2005, 73). The general committee already included two archaeologists: Witold Hensel representing the IHKM and Józef Kostrzewski for the Polish Archaeological Society (Polskie Towarzystwo Archeologiczne). With the appointment of scientific commissions accompanying the planning works of the KPOTPP an archaeological commission was formed, too (Noszczak 2002, 121 and 258). Headed by Hensel, it swiftly produced an agenda for archaeological activities related to the millennium (Archiwum PAN zesp. Manteuffel, T. Sygn. III-192, 61, 25-27). This program focused on a re-intensification of excavation works and the analysis of relevant discoveries in the upcoming two years while planning a number of popularizing means like publications, conferences, exhibitions and media covered presentations later on. Thus the commission applied for respective funding, seemingly attempting a revival of the KBnPPP research program (Archiwum PAN zesp. Manteuffel, T. Sygn. III-192, 61, 25-27). The tasks laid ahead for Polish archaeologists to prepare and support the millennial celebrations were also discussed in academic journals and popular-scientific magazines. Hensel in particular stressed the necessity of further excavation campaigns, arguing that many questions remained unresolved despite the KBnPPP's achievements. New research investments could deepen the investigations at places like Gniezno, Poznań, Kruszwica, Giecz, Kalisz, Międzyrzecz, Santok, Wrocław, Opole, Kraków, Stradów, Łęczyca, Gdańsk, Szczecin, Kołobrzeg, Płock and Czermno or Włocławek and Głogów, and lead to a "proper synthesis of the early feudal history of Poland"11 (Hensel 1958a, 227; 1958b, 949). Apart from the suggested excavation, publication

11 " “...] dla uzyskania właściwej syntezy dziejów Polski wczesnofeudalnej niezbędna będzie w najbliższych latach intensyfikacja prac wykopaliskowych w takich ośrodkach [...]" (Hensel 1958a, 227). 
and exhibition works (Breyer 1968, 93; Kobyliński/ Rutkowska 2005, 78 and 108f.) the organization of the first international Congress for Slavic Archaeology became a central project within the discipline's millennial contributions (Hensel 1958a, 950f.), offering an opportunity to internationally discuss Slavic ethnogenesis and show off the highly developed material culture of early medieval Poland (Hołubowicz 1958, 70f.).

According to Noszczak $(2002,122)$ the overall KPOTPP approved of the following aspects proposed by the archaeological commission: to concentrate excavation activities at selected early Piast central places until 1960, while the following years were to be devoted to work on special key issues related to occurring anniversaries and the general conception of the millennium celebrations. Further acknowledgement received the publication project „Millenium Poloniae Monumenta Archaeologica” and the intensification of scholarly exchange between Poland and the Soviet Union, the ČSSR and GDR (Noszczak 2002, 122).
It is difficult to determine exactly to which extent the mentioned activities were actually financed and realized. Published IHKM reports mention financial subsidies explicitly connected to the millennial celebrations only for the year 1959, dedicated to publications and the installation of a scientific laboratory (Pazdur 1960, 425f.; 433). "Millennial funding" (,subwencje Tysiąclecia“) was also mentioned by Włodzimierz Hołubowicz to subsidize the excavation program of the IHKM branch in Wrocław in 1958 (Hołubowicz 1958a, 1; 1958b; 1959, 4f.).

Aside from several sessions and conferences with reference to the Millennium (Noszczak 2002, 149f.; 157f.; Kobyliński/Rutkowska 2005, 102), the Slavic Archaeology Congress in Warsaw 1965 seems to have been the highlight of academic archaeological endeavours to recognize the anniversary. Planned since 1957, the congress was explicitly supported by the government and integrated in the state-controlled preparations of the Millennium (Noszczak 2002, 150-154; Zaremba 2011, 322).

\section{POLITICAL (RE-)ORIENTATIONS}

The political significance and orientation of the millennial research has been assessed rather differently if not contrarily. It is however usually agreed that the early concept of the millennial program was developed in the post-war national-patriotic, anti-German sentiment along with the efforts to integrate the new (North-)Western territories. This spirit is generally assigned to the Polish Western Thought, the Myśl Zachodnia, referring to the programmatic idea of a territorial claim to the incorporation of lands West of the 1772 Polish border as a necessity for a strong and independent Poland. It was connected to the discourse of the Polish-German relations understood as an eternal struggle for territories and power (Jaworski 1993, 95; Brier 2003, 3).

Forming a centre of research on this issues already during the inter-war period, Poznań became the seat of the Western Institute in 1944/45 (Brier $2003,12)$. In the first post-war years the communist government resorted to national(ist) attitudes as a legitimation strategy to enforce their claim to leadership as well as for the Westward shift of the Polish borders (Zaremba 2011, 145-184). Hence, scholarly contributions to the ideological integra- tion of the Western territories and to justify the dependence on Soviet support against the perpetually threatened border to Germany were welcomed and funded.

The Poznań Archeological Centre stood in close relations to the Western Institute since Kostrzewski, Hensel and Rajewski belonged to its members and even supervised an archaeological section existing from 1945 to 1946 (Kaczmarek 1996, 260f.; Anonymous 1946, 295). Thematic synergies arose especially from the question of the proto-Slavic prehistory of Poland, but also the origin of Polish statehood and the first Piast rulers (Żak 1971, 47; Brier 2003, 48). Representatives of the Western Institute were invited to the Warsaw conference in 1948 preparing the launch of the millennium program, which in turn afterwards used the institute's periodical Przeglad Zachodni for its first reports. All of the initial protagonists, i.e. Hensel, Lorentz and Gieysztor, emphasized during the KBnPPP's formation phase the political impact the millennial research could have when focussing on the Western territories. Hensel generally characterized the "twofold aspect" of works in the "regained territories" as "political and sci- 
entific" (Hensel 1946, 200) ${ }^{12}$. With regard to the selection of the sites to be investigated, both Gieysztor and Lorentz felt obliged to take into account "political needs", stressing the importance of the "scientific maintenance" of the Western territories (Gieysztor 1948, 404) ${ }^{13}$ and therefore the requirement to concentrate the suggested works in the beginning particularly on those areas (Gieysztor 1948, 411) $)^{14}$.

Even decades later, Gieysztor acknowledged again that the KBnPPP research indeed had focused on these territories, as an "important propagandist trump", even though the actual investigations were of course "truly scientific and honestly factual" 15 (Jarocki 1996). He also recollected that Lorentz had obtained such generous financial support from the government by arguing that the results of this endeavour could prove the presence of the Slavs in the "regained territories" (Jarocki 2001, 205).

Ryszard Kiersnowski related a contradicting memory, stating the Millennium program was not an institution in the service of the state because of the investigated sites being evenly spread throughout the whole country and thus, so he must have implied, did not show any preference for the Western Territories (Noszczak 2002, 62) ${ }^{16}$. The distribution of those KBnPPP sites mentioned above on the map shows however an unsurprising concentration in the area of Greater Poland and smaller clusters in Lesser Poland, the Southeast and Silesia, as well as some singular sites in the Northwest (fig. 1). Yet, taking into account duration and dimension of the executed excavations and the intensity of process-

12 "Podwójny wreszcie aspekt mają prace na Ziemiach Odzyskanych: polityczny i naukowy." (Hensel 1946, 200).

13 "Do nich zaliczyć wypada przede wszystkim potrzeby polityczne, uwydatniające wagę naszego zagospodarowania, również naukowego, Ziem Zachodnich" (Gieysztor 1948, 404).

14 "Pożądane jest na początku zawężenie terytorialne prac z uprzywilejowaniem ziem zachodnich" (Gieysztor 1948, 411).

15 "Te badania przeprowadzone były, w znacznej mierze, na obszarze Ziem Zachodnich, zwanych wtedy Odzyskanymi. To był ważny atut w rękach propagandy, choć nasze badania były naprawdę naukowe, uczciwe merytorycznie" (Jarocki 1996).

16 '“[...] że 'Milenium' nie było instytucją usługową na rzecz państwa, świadczy samo rozmieszczenie badań wykopaliskowych. Ono objęło względnie równorzędnie całą dzisiejszą Polskę" (Noszczak 2002, 62, statement by Kiersnowski). ing, analysing and discussing their results might change the picture again (Wołoszyn in print).

Jacek Lech however, taking into account the potential focus on the former German territories against the background of post-war struggles and sentiments among the traumatized Polish society, came to the conclusion that " $\mathrm{t}]$ he programme was also intended to help integrate with Poland the, previously German, western and northern territories [...]. This was undoubtedly placing scholarship archaeology and history - in the service of the state and society" (Lech 2004, 49).

On the other hand Kiersnowski in general seemed to glorify the millennial program as he was the one describing it as "an oasis in the worst time of Stalinism" (Noszczak 2002, 61). Even though there might have been a "constructive climate" as Noszczak concludes in his detailed study (Noszczak 2002, 55), and contemporary scholars remember archaeology as less subjected to ideological pressure and political control than the historic science (Kurnatowska 1997c, 182), it seems to be unrealistic to believe the KBnPPP completely free of Stalinist repressions. The height of Stalinism went along with the consolidation of the communist regime, and thus with turning away from the nationalpatriotically integrating line of the former years towards emphasizing the revolutionary traditions and bonds of international Communism (Zaremba 2011, 185-206). The turn in cultural and educational politics, the transformation of academic structures and the adjustment to Marxist philosophy were consequences affecting the humanities.

At least officially and formally the Kierownictwo Badań had to and did introduce the Marxist methodology in Stalinist reading, regardless of how successful and lasting its theoretical and methodological impact was in the end. Official statements attested the KBnPPP a successful role in initiating or contributing to the methodological conversion, like Majewski in 1954 stating a general agreement "that the 'Kierownictwo Badan' initiated the methodological conversion of the archaeology in Poland on the principles of Historical Materialism, the transition from the 'Prehistory of Poland' to the Marxist position of a history of ancient Poland" (Archiwum PAN zesp. Majewski, K. Sygn. III-275, jedn. 30, 26) ${ }^{17}$.

17 “Otóż wiadomo nam i co do tego jesteśmy wszyscy zgodni, że ‘Kierownictwo Badań’ zainicjowało przebudowę 


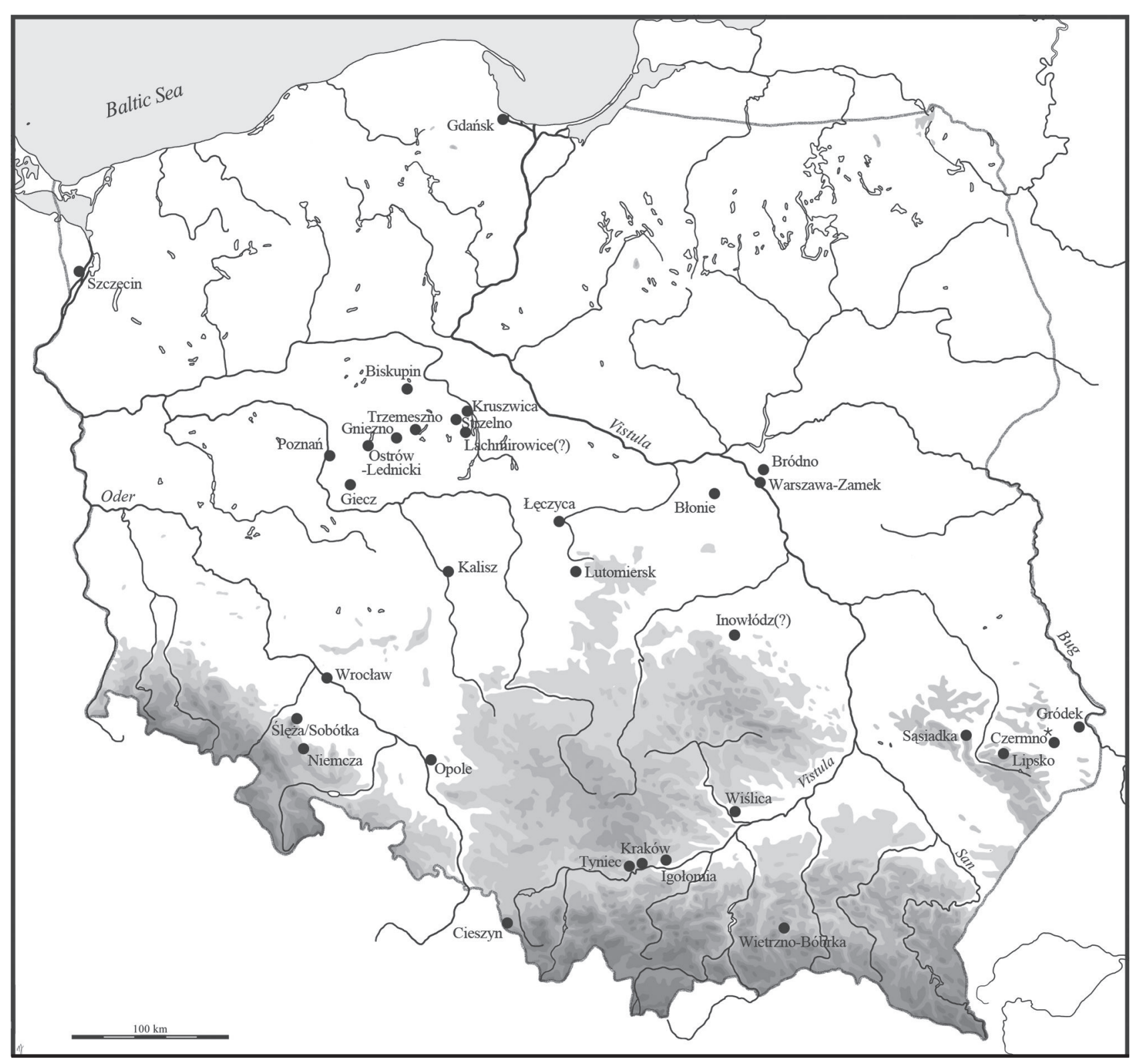

Fig. 1. KBnPPP sites 1948-1953 (cf. Gieysztor 1953, 10f.; Noszczak 2002, 257 Aneks; AAN MKiSz Akta tajne paczka 1, t. 3, cz. II, poz. 124; AAN MKiSz Dyr. Muz. 3/141 and 3/142). Map provided by Irena Jordan.

(?) Lachmirowice and Wietrzno-Bóbrka/Krosno are not mentioned by Gieysztor 1953 or Noszczak 2002, but in a report about the excavation season 1951 (AAN MKiSz Dyr. Muz. 3/142)

* The Cherven' towns/Grody Czerwieńskie, i.e. Czermno, Gródek, Sąsiadka and Lipsko-Polesie, do not appear as regular KBnPPP sites, its association with the KBnPPP is complicated (see Marcin Wołoszyn's contribution to this volume).

In this sense, Piotr Hübner, as a historian concerned with the history of post-war historiography, understood the Kierownictwo Badań actually as the „implementing organ for the state's science policy” (Hübner 1987, 461). Also, he quotes an internal document of the PAN from 1953, asserting that the

metodologiczną archeologii w Polsce na zasadach materializmu historycznego, przejście z 'prehistorii Polski' na pozycje marksistowskie historii Polski starożytnej." (Archiwum PAN zesp. Majwski, K. Sygn. III-275, jedn. 30, 26).
KBnPPP was instigated to bring about the methodological conversion on the basis of Historical Materialism (Hübner 1987, 462).

Against this background the reinforced cooperation with historians could have been functioned not only to look up potential important places for the beginnings of the Polish state in medieval sources, but perhaps also to advance the process of Stalinization since the concept of historical materialism was introduced earlier among historians (Lech 1997/98, 85). 
With the Thaw period leading into post-Stalinism, national-patriotic orientations became reputable again or even necessary to overcome the crisis of the political system (Zaremba 2011, 231-270). In this respect the celebration of a national Millennium answered political demands anew. Numerous politicians during their speeches in tribute to the millennial festivities of the 1960s referred to the results of the KBnPPP's research achievements as evidence proving that Poland and especially its Western Territories had always been Polish.

The many quotations by political dignitaries collected by Zbigniew Kobyliński and Grażyna Rutkowska $(2005 ; 2006)$ show how much archaeological achievements were perceived and then further spread by government representatives, the general public and the daily press, during the years of celebrating the Millennium in particular. From this perspective archaeologists (and historians) appeared fundamentally involved in providing "proof" for the "polskość", i.e. the Polishness, as well as the long proto-Slavic past and the general Slavic imprint of the Western territories. They seemed to be capable of refuting apparently chauvinistic and revisionistic theses postulated by pre-war Eastern and post-war
Western German archaeology, and of accounting for the extraordinary cultural height of Poland's early medieval "ancestors", as the following statement of deputy prime minister Piotr Jaroszewicz on the occasion of opening the millennial festivities in Kalisz shows, "[a]nd thanks to the persistent and successful work of our archaeologists and historians, myths, legends and occasionally even erroneous views are being gradually replaced by a picture of our homeland from a thousand years ago, slowly brought out from the darkness of the past, a state with civilizational achievement no less than other contemporary peoples" (Kobyliński/Rutkowska 2005, 78; cf. also 84 fn. 49).

This corresponds with Hensel's view on the role archaeology could assume in connection with the millennial celebrations, regarding the use of scientific results for mass propaganda as one of its possible contributions (Hensel 1958a, 951) ${ }^{18}$. He regarded the research on the beginnings of the Polish state as an archaeological task continuing "those conceptions, traditions and the effort of a society that tencenturies ago brought about the formation of our national existence on the Oder, Warta and the Baltic Sea" (Hensel 1958b, 225) ${ }^{19}$.

\section{CONCLUSION}

The millennial research from the very beginning reflected changing political needs. Its structural transformations from the initial idea to an institutionalised program headed by the KBnPPP, to its conveyance into the IHKM and up to the latter one's contributions to the millennial celebrations seem to have followed those needs.

At first it fitted the post-war national-patriotic sentiments as well as the ideological integration of the "regained territories" and thus went conform with consolidating strategies of the communist rulership described by Marcin Zaremba $(2001 ; 2011)$ as national legitimation. With its incorporation into governmental structures the research on the beginnings of the Polish state received likewise funding and control.

Due to Stalinism and the increased integration of the Western territories this orientation lost importance while the formal transformation into communist structures of centralization was ultimately executed with the transference of the millennium research program into the academy Institute for the History of Material Culture. The methodological conversion on the basis of Historical Materialism already pursued within the framework of the $\mathrm{KBnPPP}$ was to be completed within the new institute's conjunction of different disciplines related to the study of material culture.

Along with the government's post-Stalinist return to national-patriotic attitudes, especially in relation to the state festivities of the Polish Millennium in the 1960s, the achievements of the KBnPPP received significance once more as reference, evidence and illustration for the centuries-old Polish character and entitlement to this country.

\footnotetext{
18 “współpraca w upowszechnianiu wiedzy przy pomocy tzw. środków masowej propagandy” (Hensel 1958a, 951).

19 "Dziś przecież jesteśmy kontynuatorami tych koncepcji, tych tradycji i tego wysiłku społeczeństwa, które doprowadziły przed 10 wiekami do ukształtowania naszego bytu państwowego nad Odra, Wartą i Bałtykiem." (Hensel $1958 b, 225)$.
} 


\section{BIBLIOGRAPHY}

AAN MKiSz. Archiwum Akt Nowych, zespół Ministerstwo Kultury i Sztuki.

Abramowicz A. 1991. Historia archeologii polskiej XIX i XX wieku. Warszawa-Łódź.

Anonymous 1946. Bilans I roku pracy Instytutu Zachodniego. Przeglad Zachodni 1946/1, 291-298.

Anonymous 1970. Kazimierz Majewski. Z Otchłani Wieków 36 (2), 182-185.

Anonymous 1974. Aleksander Gieysztor. Z Otchłani Wieków 40 (4), 298-300.

Archiwum PAN. Archiwum Polskiej Akademii Nauk.

Barford P. 1993. Paradigms lost: Polish archaeology and post-War politics. Archaeologia Polona 31, 257-270.

Barford P. 1995. Marksizm w archaeologii polskiej w latach 1945-1975. Archeologia Polski 40/1-2, 7-78.

Barford P. 1997. Małowiarygodny? Odpowiedź na polemikę pana Jacka Lecha. Archeologia Polski 42/1-2, 233-248.

Barford P. 2002. Reflections on J. Lech's vision of the history of „Polish“ archaeology. Archaeologia Polona 40, 171-184.

Breyer R. 1968. Die polnische Milleniums-Diskussion zwischen Geschichtswissenschaft und Ideologie. (In:) R. Breyer (ed.), Probleme der Wissenschaft im heutigen Polen. Marburg, 85-104.

Brier R. 2003. Der polnische Westgedanke nach dem Zweiten Weltkrieg (1944-1950). Digitale Osteuropa-Bibliothek 3. http://epub.ub.uni-muenchen.de/546/1/brierwestgedanke.pdf

Borodziej W. 2010. Geschichte Polens im 20. Jahrhundert. München.

Brzostowicz M. 2014. Osiągnięcia Józefa Kostrzewskiego w badaniach nad wczesnym średniowieczem w Polsce. Fontes Archaeologici Posnanienses 50 (1), 89-100.

Buko A. 2014. Czy Józef Kostrzewski był badaczem wczesnego średniowiecza? Fontes Archaeologici Posnanienses 50 (1), 101-110.

Dęmbińska M. 1965. Dix ans d'activités de l'Institut d'Histoire de la Culture Materielle de L'Académie Polonaise des Sciences. Archaeologia Polona 8, 209-222.

Gąssowski J. 1998. Archeologia Polska. Tradycje i perspektywy. Przeglad Humanistyczny 2, 35-44.

Gieysztor A. 1948. Polskie Millenium. Z zagadnień wspótpracy historii $i$ archeologii wczesnodziejowej. Warszawa.

Gieysztor A. 1953. Kierownictwo Badań nad poczqtkami Państwa Polskiego w latach 1949-52. Warszawa.
Hensel W. 1946. Potrzeba Przygotowania Wielkiej Rocznicy (O niektórych zagadnieniach polskiej protohistorii). Przeglad Wielkopolski 7/8, 1946, 193-206.

Hensel W. 1958a. Archeologia w pracach przygotowawczych do obchodów Tysiąclecia Państwa Polskiego. Kwartalnik Historyczny 3, 948-951,

Hensel W. 1958b. Z przygotowań do polskiego Tysiąclecia. Z Otchłani Wieków 24, 225-229.

Hołubowicz W. 1954. Powołanie Instytutu Historii Kultury Materialnej. Dawna Kultura 1, 43.

Hołubowicz W. 1958a. Prace terenowe zakładu archeologii polski I.H.K.M. P.A.N. w r. 1958 i zamierzenia na rok 1959. Ślaskie Sprawozdania Archeologiczne 1, 1-8.

Hołubowicz W. 1958b. O udziale archeologii w obchodach tysiąclecia. Ślaskie Sprawozdania Archeologiczne 1, 66-71.

Hołubowicz W. 1959. Kilka uwag wstępnych o pracach terenowych Katedry Archeologii Polski Uniwersytetu Wrocławskiego i Zakładu Archeologii Polski IHKM PAN we Wrocławiu w r. 1959. Ślaskie Sprawozdania Archeologiczne 2, 3-10.

Hübner P. 1987. Przebudowa nauk historycznych w Polsce (1947-1953). Przeglad Historyczny 78, 451-481.

Jarocki R. 1996. Gieysztor jawny i niejawny (Epizody $\mathrm{z}$ lat 1944-45). Rzeczpospolita. Dodatek tygodniowy +PLUS-MINUS 28 (182) 13./14.7., 13 i 18.

Jarocki R. 2001. Opowieść o Aleksandrze Gieysztorze. Warszawa.

Jaworski R. 1993. Die polnische Westforschung zwischen Politik und Wissenschaft. (In:) E. Oberländer (ed.) Polen nach dem Kommunismus. Stuttgart, 94-105

Kaczmarek J.E. 1996. Organizacja badań i ochrony zabytków archaeologicznych $w$ Poznaniu (1720-1958). Poznań.

Kiersnowski R. 2000. Wspominając Aleksandra Gieysztora: w "Millenium". Przeglad Historyczny 41(1), 61-67.

Kobyliński Z. 1991. Theory on Polish Archaeology 19601990: Searching for Paradigms. (In:) I. Hodder (ed.), Archaeological Theory in Europe. The last three decades. London-New York, 223-247.

Kobyliński Z. 1996. Early Medieval Archaeology in Poland: Successes and Failures. World Archaeological Bulletin 8, 238-254.

Kobyliński Z., Rutkowska G. 2005. Propagandist use of history and archaeology in justification of Polish rights to the „Recovered Territories" after World War II. Archaeologia Polona 43, 51-124. 
Kobyliński Z., Rutkowska G. 2006. Propagandowe wykorzystanie archeologii $\mathrm{w}$ uzasadnianiu polskich praw do ziem odzyskanych po drugiej wojnie światowej. Saeculum Christianum 13 (2), 13-80.

Kozłowska Z.T. 2016. Szkolne kształcenie historyczne w doświadczeniu i działaniach Aleksandra Gieysztora. (In:) M. Koczerska, P. Węcowski (eds.), Aleksander Gieysztor. Człowiek i dzieło. Warszawa, 73-80.

Kurnatowska Z. 1997a. Czy Millenium było ,tragedią polskiej archaeologii“? (In:) M. Głosek (ed.), Archeologia i starożytnicy. Studia dedykowane Profesorowi Andrzejowi Abramowiczowi w 70 rocznice urodzin. Łódź 1997, 147-156.

Kurnatowska Z. 1997b. Badania nad początkami państwa polskiego. Próba bilansu. Slavia Antiqua 38, 25-38.

Kurnatowska Z. 1997c. Interview von Andrzej Sikorski mit Zofia Kurnatowska. (In:) R. Brzezińska (ed.), Poznaniacy. Portretów kupa i trochę, II. Poznań, 182-185.

Lech J. 1997. Małowierni. Spór wokół marksizmu w archeologii polskiej lat 1945-1975. Archeologia Polski 42, 175-232.

Lech J. 1997/98. Between captivity and freedom: Polish Archaeology in the 20th century. Archaeologia Polona 35/36, 25-222.

Lech J. 2002. On Polish archaeology in the 20th century: remarks and polemics. Archaeologia Polona 40, 185252.

Lech J. 2004. Polish-German relations in archaeology in a short outline: a view from Warsaw. Archaeologia Polona 42, 21-64.

Lech J. 2007. O archeologii polskiej w latach 1939-1989słowo wstępne. (In:) J. Lech (ed.), Pót wieku z dziejów archeologii polskiej (1939-1989), Warszawa, 9-24.

Lorentz S. 1956. Museen und Sammlungen in Polen 19451955. Warszawa.

[Majewski] K. 1953. Sprawozdanie z działalności Podkomitetu Historii Kultury Materialnej i Komisji Organizacyjnej Instytutu Historii Kultury Materialnej Polskiej Akademii Nauk. Kwartalnik Historii Kultury Materialnej 1, 284-291.

Moździoch S. 1997. Problemy badań nad początkami miast i wsią wczesnośredniowieczną w Polsce. Slavia Antiqua 38, 39-63.

Moździoch S. 2008. Ein Land, wo „Milch und Honig fließt". Die ersten Piasten als Wirtschafter ihres Landes. (In:) D. Bulach, M. Hardt (eds.), Zentrum und Peripherie in der Germania Slavica. Beiträge zu Ehren von Winfried Schich. Forschungen zur Geschichte und Kultur des östlichen Mitteleuropa 34. Stuttgart, 265-278

Moździoch S. 2009. Wishful digging - Burgwallforschung im Rahmen des polnischen Millenium-Projektes. (In:)
S. Rieckhoff, S. Grunwald, K. Reichenbach (eds.), Burgwallforschung im akademischen und öffentlichen Diskurs des 20. Jahrhunderts. Leipziger Forschungen zur Ur- und Frühgeschichtlichen Archäologie 5. Leipzig, 139-153.

Noszczak B. 2002. "Sacrum" czy ,profanum"? - Spór o istote obchodów milenium polskiego (1949-1969). Warszawa.

Pazdur J. 1960. Z działalności Instytutu Historii Kultury Materialnej PAN. Kwartalnik Historii Kultury Materialnej 8, 425-434.

Reichenbach K. 2016. Millionen für's Millenium. Finanzierung und Ausstattung der Forschungen $\mathrm{zu}$ den Anfängen des polnischen Staates 1949-1953. (In:) S. Grunwald, U. Halle, D. Mahsarski, K. Reichenbach (eds.), Die Spur des Geldes in der Prähistorischen Archäologie. Mäzene - Förderer - Förderstrukturen. Bielefeld, 259-280.

Rutkowski T.P. 2013. Różne barwy przystosowania. Wokół działalności Aleksandra Gieysztora w PRL. Annales Universitatis Paedagogica Cracoviensis. Studia Politologica 9, 138-156.

Schild R. 2013. Polish Archaeology in transition. Antiquity 67 (1), 146-150.

Stobiecki R. 2006. Między kontynuacją a dyskontynuacją. (In:) U. Jakubowska, J. Myśliński (ed.), Humanistyka polska w latach 1945-1990. Warszawa, 127-153.

Tabaczyński S. 1995. A Future for the Marxist Paradigm in Central European Archaeology? The Polish Case. (In:) M. Kuna, N. Venclová (eds.), Whither Archaeology? Papers in Honour of Evžen Neustypný. Praha, 69-81.

Tabaczyński S. 2007. Polish archaeology in my lifetime. Antiquity 81 (314), 1074-1082.

Tabaczyński S. 2009. Quo Vadis Archaeologia? The Present and the Future of the Research about the Past: Polish Experiences. (In:) J. Schachtmann, M. Strobel, T. Widera (eds.), Politik und Wissenschaft in der prähistorischen Archäologie. Perspektiven aus Sachsen, Schlesien, und Böhmen. Berichte und Studien 56. Dresden, 317-333.

Urbańczyk P. 2000. Political circumstances reflected in post-war Polish archaeology. Public Archaeology 1, 49-56.

Urbańczyk P. 2008. Wywiad z profesorem Witoldem Henslem. Archeologia Polski 53/1, 147-159.

Węcowski P. 2016. Listy Aleksandra Gieysztora (wybór). (In:) M. Koczerska, P. Węcowski (ed.), Aleksander Gieysztor. Człowiek i dzieło. Warszawa, 349-568.

Wołoszyn M. in print. Wie betreibt man Archäologie in einem Land, in dem es nur um ,warmes Wasser aus dem Wasserhahn“ geht? Zur frühgeschichtlichen Ar- 
chäologie in Polen nach der Wende. (In:) J. Drauschke, R. Prien (eds.), Quo Vadis Frühgeschichtliche Archäologie? Studien zu Spätantike und Frühmittelalter 9. Hamburg.

Wysocki J. 1997/98. The protection of the archaeological heritage in Poland in the 20th century: concepts and practices. Archaeologia Polona 35/36, 427-452.

Zaremba M. 2001. Komunizm, legitymizacja, nacjonalizm. Nacjonalistyczna legitymizacja władzy komunistycznej w Polsce. Warszawa.

Zaremba M. 2011. Im nationalen Gewande. Strategien kommunistischer Herrschaftslegitimation in Polen 1944-1980. Osnabrück.

Author's address:

Karin Reichenbach M.A.

Leibniz-Institute for the History and Culture of Eastern Europe (GWZO)

Specks Hof (Eingang A), Reichsstraße 4-6

D-04109 Leipzig

e-mail: karin.reichenbach@leibniz-gwzo.de
Zeydler-Zborowski Z. 1954. Zeydler-Zborowski, Instytut Historii Kultury Materialnej Polskiej Akademii Nauk. Dawna Kultura 1, 93-94.

Żak J. 1971. Prahistoria. (WIn:) Z. Kaczmarczyk (red.), Problematyka polsko-niemiecka i polskich ziem zachodnich w badaniach Uniwersytetu im. Adama Mickiewicza w Poznaniu (1919-1969). Poznań, 37-51.

Ż[aki ?] A. 1948. Kronika. Od Redakcji. Z Otchłani Wieków 17 (styczeń-luty), 28-29. 